\title{
Prophet Muhammad and His Western Critics
}

By Zafar Ali Qureshi. Mansoorah, Pakisan: Idara Maarif Islami, 1992, 2 vols.

Modern Orientalists generally boast of their objective analysis and impartial approach to problems, but facts belie their loud claims when their research comes down to the study of the Prophet. In this case, deep prejudices are reflected in their writings. Sometimes they indulge in frontal attacks on him, while at other times they hit him below the belt. They try to give an impression that the time in which the message of Islam was spread was ripe for revolution, independent of the Prophet. So to them, the Prophet's contribution was to make a 
correct assessment of the prevailing situation and then make use of the opportunity provided to project his viewpoint. The ultimate aim of such endeavors on the part of Orientalists is to belittle the historic role of the Prophet and to unsetthe the Muslim consciousness of its cognitive certainty of the divine revelation to the Prophet.

The author asserts that the Prophet brought about a complete revolution in the lives of his early followers. After embracing Islam, they no longer remained the old Arabs; they became God-fearing and pious folk who were very concerned with the life hereafter rather than riveting their attention on material considerations. In view of these realities, it is highly callous on the part of Reverend Watt to denigrate Muslims for what they sought to accomplish. No fair-minded historian would point out any character failing in these noble men. Also, they could not simply think of invading neighboring lands, as Watt would have us believe. Likewise, Watt's whole chain of hypotheses about the economic and political reasons for the emigration to Abyssinia is without foundation.

Watt's attempt to castigate the Prophet, Abū Bakr, and other Muslims fails, as does his quest to play down the untold hardships and persecutions suffered by Muslims at the hands of the pagan Quraysh. As is well known, the Quraysh forced the Muslim to emigrate to Abyssinia, which was considered a safe haven for the persecuted early Muslim community.

Watt tries to belittle the revolutionary spirit of the message by relating it to mere economic or political considerations. This is indeed a gross distortion of history. Likewise, he seeks to downplay the severe persecution perpetrated on Muslims and the Prophet. By doing so, Watt indulges in a complete distortion of historical realities. Here are a few instances that Watt has quoted, which are quite contradictory in nature.

The author is convinced that Prophet Muhammad had a universal appeal and that his message was not to the people of Makkah alone. He was a Prophet of God who was appointed by God to establish His sovereignty. To this end, he had devoted all his energies and worked with complete devotion and steadfastness until the completion of his mission. Watt knowingly and willfully ignores the point that the Prophet's vocation and mission were the propagation of the unity of God and the condemnation of idolatry in every shape and form. He directed all his energies to this focal point, not to any idea of nationality or country or race, which is suggested by Watt, who consistently seeks to decrease the revolutionary appeal of the Prophet's mission by stressing material considerations that, in reality, had hardly anything to do with the true role of the Prophet.

The author notes that by their conversion to Islam, a great moral and spiritual transformation was wrought in the lives of early Muslims and that, after this event, they were willing to sacrifice everything for the sake of their faith. In fact, they had proved by their actions that they preferred to leave their hearths and homes and lead lives of hardship, privation, and misery in foreign places rather than compromise in the matter of their faith and the freedom of their conscience.

Western writers invariably assert that the Prophet used force to propagate Islam. These are all false allegations. We are convinced that had the Prophet been inclined to follow a policy of forced conversion to Islam, no better opportunity could have come his way, at least in the case of the Jewish and Christian tribes, than the expedition of Tābük, when he led a formidable force of thirty thousand strong warriors - the biggest army ever assembled in Arabia in those times-and yet this did not happen. 
In sum, Zafar Ali Qureshi has refuted convincingly all of the baseless allegations leveled against the Prophet. In the process, he has vindicated successfully the Prophet's good name and honor. He has also taken care to follow the research methodology according to the exact standards of modem scholarship. It is hoped that his work will provide both an oppornunity and an incentive to Muslims to listen to the revolutionary message of the Prophet.

Col. (Retd.) Ghulam Sarwar Rawalpindi, Pakistan 